\title{
Western Equine Encephalomyelitis
}

National Cancer Institute

\section{Source}

National Cancer Institute. Western Equine Encephalomyelitis. NCI Thesaurus. Code C85227.

A mosquito-born viral infection caused by the Western equine encephalitis virus. The signs and symptoms range from flu-like illness to permanent central nervous system damage, coma, and death. 